\title{
Penny wise: penny foolish
}

\author{
Henry R. Rollin
}

"In the country of the blind the one-eyed man is king". Similarly, in the institution for the care of what Victorian alienists described as those "distinctly deficient in mental powers", the patient with an 18 of, say, 80 had a distinct advantage over another with an IQ of, say, 60 .

This truism is poignantly illustrated by a tragicomedy I witnessed, not in Victorian times, but only a matter of half-a-century or so ago when, as a fledgling psychiatrist, I was employed at an institution designated for the care of the likes of those described above.

In those days tobacco was the opium of the mass of patients, as important a sedative as paraldehyde or bromide. The sale of cigarettes, overwhelmingly the commonest vehicle for tobacco, was posittvely encouraged, and to this end simple vending machines were distributed at a variety of vantage points throughout the institution. There was no choice, however. The only cigarettes available came in slim, green, paper packets containing five 'Woodbines'. The modus operandi was simple enough: the would-be purchaser inserted two 'old' copper pennies oneby-one into a slot at the top of the machine, let them drop and then pulled a drawer at the bottom and, prestol, five 'woodies' were delivered.

One morning I emerged from a side corridor at a time when two of my patients arrived simultaneously at one of the machines and I was able to see and hear what went on without being seen or heard.

Said Alfie, street-wise and substantially less deficient in mental powers than Bert, "Say, Bert. Do you know 'ow to get a packet of fags for a penny?". "You're 'aving me on", retorted Bert. "They cost tuppence". "You wanna see 'ow it's done?", replied Alfie with a decided air of authority. "Oright. You show me", agreed the somewhat sceptical Bert. "Put your penny in, then" commanded Alfie, a command which Bert with some reluctance obeyed. "Now, pull the drawer". The drawer, of course, remained stubbornly shut much to the consternation of the unfortunate Bert. Before he could voice his protestations, however, Alfie elbowed his way to the front of the machine saying with patronising superiority, "Now watch me", whereupon he dropped his penny into the machine, nonchalantly gave the drawer a tug and, surprise! surprisel, it opened.

Alfie gathered the packet of fags and cockdly sauntered away leaving the bewlldered Bert no wiser and a penny poorer for his first lesson in conmanship.

Henry R. Rollin, Emeritus Consultant Psychiatrist, Horton Hospital, Epsom 